\title{
Work and Labour as Metonymy and Metaphor
}

\author{
Olivier Frayssé
}

\author{
Université Paris-Sorbonne, HDEA-TCS, Paris, France, Fraysseo@aol.com, http://www.paris- \\ sorbonne.fr/presentation-5414
}

\begin{abstract}
This paper proposes to use the tools of literary analysis (the reference to subtexts) and of linguistics (metaphor and metonymy) to shed light on the work/labour controversy and, beyond that, to map the galaxy of representations of work/labour through a study of the meanings associated with work/labour in several languages. It aims to provide a set of theoretical tools that can be used to find a common language in order to discuss digital work/labour issues as a subcategory of work/labour issues in general.
\end{abstract}

Keywords: work, labour, metonymy, metaphor, subtext, cognitive linguistics.

Acknowledgement: In addition to the dictionaries mentioned in the bibliography, I have relied on the help of several friends and colleagues who were more familiar than me with the languages I have tried to approach, and to recognized experts in the field of linguistics. In particular, I would like to express my warm thanks to my colleagues Professors Leo Carruthers (Old English), Pierre Cotte (Linguistics), Frédéric Lagrange (Arabic), Laure Troubetzkoy and Stéphane Viellard (Russian) Dr. Eran Fischer (Hebrew), to my doctoral student Medina Niang (Woloff), to my friends Shuai Zhang (Chinese) and Daniel Koechlin (Sanskrit and Gaelic), and to my son David (Lingala and Swahili). Special thanks to my friend and colleague Dr. Barbara Lelan, who, among her many other insights, especially regarding sign languages, has led me along the path to metonymy as fractal compression, and Ursula Huws, who directed me to relevant sources for the vocabulary of digital work and labour, and the reviewers of this paper, who forced me to answer very interesting questions.

\section{Introduction}

There is an ongoing discussion on the difference between work and labour. In the Marxist tradition, the word labour has been associated with alienated and exploited work, a historical category, as opposed to work, an anthropological category, quintessential to the human species (Fuchs and Sevignani 2013). This paper is a modest contribution to the debate, from the angle of linguistics in the broad sense of the word.

Work/labour is an elusive notion in many ways. I am using the phrase work/labour as a provisional notion in order not to take sides at the beginning of the investigation, and also because, in several languages, such as French (travail) or German (Arbeit), there is but one word, so that the speaker needs to use a modifier to convey the precise meaning he/she gives to the word (abstract/concrete, living/dead, etc.) within his/her theoretical framework. When translated into English, the word becomes either work or labour, depending on both the translator's understanding of the original meaning within the original theory, and his or her own theoretical view that has associated either work or labour, possibly with modifiers, with one concept or another. There is plenty of room both for misunderstandings and competing translations. Arbeitsproze $\beta$ is thus translated either by labour process or work process depending on the theoretical views of the translator, and sometimes he/she uses the two indifferently.

There is another difficulty. Whenever one tries to define the notion either some aspects of work/labour are excluded or the definition stretches too far to be useful. Try Marx's often quoted definition of the "labour process" or "work process" (Arbeitsprozeß), depending on the translation and the context as "human action with a view to the production of use-values, appropriation of natural substances to human requirements", "zweckmäßige Tätigkeit zur Herstellung von Gebrauchswerten, Aneignung des Natürlichen für menschliche Bedürfnisse", (Marx 1990, 290, Marx and Engels 1968ff, 24 and 198). It can be stretched to such an extent that most bodily functions such as eating could be included if we consider only tangible use- 
values, while kicking stones along the path, scratching one's beard and every form of play could be added if we included intangible use-values.

A third difficulty comes from the connotations of the words work and labour, which vary depending on the texts, the contexts, and the subtexts. In particular, the words work and labour will be referred to more or less explicitly when using other words, either as particular aspects of work/labour, or by opposition. Talk of drudge, chore, toil, on the one hand, or play, rest, idleness on the other, and a particular aspect of work/labour comes to mind. The words work and labour belong to a galaxy of representations that comprises many words, and a complete vision of the galaxy is required to help us choose the right definition/translation in each instance. The organization of this galaxy enables one to identify the sometimes hidden and unconscious dimensions of the work/labour concept.

This paper proposes to use the tools of literary analysis (the reference to subtexts) and of linguistics (metaphor and metonymy) to shed light on the work/labour controversy and, beyond that, to map the galaxy of representations of work/labour, through a study of the meanings associated with work/labour in several languages, both Indo-European and non-IndoEuropean. The list of languages studied here is reduced, and both my own limited knowledge of the languages and the lack of space to explore further the relevant lexicon in each language restrict the validity of the research findings. What is hoped nevertheless is that the tentative classification that results, which points to anthropological constants and historical variables, can serve as a starting point for a more extensive (in terms of the number of languages covered) and comprehensive (in terms of the number of metonymies used for classification) mapping of this galaxy of representations. But to shed light on the work/labour controversy between Marxists and non-Marxists, and different interpretations of Marx, I would like to start with the subtext of Engels' footnote, Adam Smith's Wealth of Nations.

\section{The importance of Subtexts in the Work/Labour Controversy}

A footnote of Friedrich Engels to the fourth German edition of Marx's Capital claimed that "the English language has the advantage of possessing two separate words for these two different aspects of labour" (Marx 1990, 138n16), so that the former could be used for all productive activities, regardless of their social context, while the latter was associated with what makes these productive activities useful for capital, that is the generation of surplus value.

As a matter of fact, the distinction between work and labour is not germane to English as a lexical distinction, it is "a split that few people can make sense of in the English-speaking world" (Kley 2008, 12). While there is no commonly accepted lexical distinction between the words work and labour, as words, in general, in the English language, there are distinctions arising from the contexts. One cannot substitute "work" for "labour" when speaking of the Labour unions, nor can one say he or she is looking for "labour" when in quest of employment.

There are also distinctions arising from subtexts. A subtext is a text to which another text refers, usually implicitly. Just like contexts, subtexts are often indispensible for us to ascertain the precise meaning of a word for which there exists a variety of lexical definitions. For instance, a sizeable part of the New Testament has the Old Testament as a subtext, and no scientific exegesis can ignore this subtext. The importance of subtexts is particularly relevant to the work/labour controversy between various schools of Marxists and non-Marxists. Since the subtexts are the theoretical works in the English language studied by Marx and Engels, the distinction is a conceptual one, which only some people, interested in theory, will make. The relative plasticity of language enables one to assign precise definitions to words according to one's theoretical preoccupations. For instance, Free-Masons would assign special meanings (as distinct from lexical differences accepted by every speaker of the language) to the words labour, work, and business, according to their own vision of the world, and the place of their philosophy, that glorifies work/labour in all its shapes: "It is one of the most beautiful features of the Masonic Institution, that it teaches not only the necessity, but the nobility of labor. From the time of opening to that of closing, a Lodge is said to be at labor. 
[...] When the lodge is engaged in reading petitions, hearing reports, debating financial matters, etc., it is said to be occupied in business; but when it is engaged in the form and ceremony of initiation into any of the degrees, it is said to be at work" (Mackey 1914, 419).

Is then the Marxist distinction between work and labour, which does not rest on a lexical distinction, a purely arbitrary one, born of Marxian theory and forced into a lexical distinction for adherents of the theory, who then would have to go to great lengths to try to justify the distinction as a lexical one, using etymology for instance? Was Engels ignorant of the absence of any commonly accepted lexical difference, except in particular contexts? Or was there, within the context of the particular lexical field of nascent political economy, a subtext that legitimated the distinction? As a matter of fact, there was, as we can see when we analyze one of the principal subtexts of Marx's work, and Engels's footnote, i.e. the use of the word labour by Adam Smith, with whose work Marx and Engels were very familiar (there are 72 references to Smith in the 1844 manuscripts, versus only 19 for Jean-Baptiste Say for example).

In Wealth of Nations (1999), Smith uses the word work to mean several different things: in Book I, chapter I, "Of the Division of Labour", it means alternatively the productive tasks to be done in a manufacture, ${ }^{2}$ the nature of the tasks performed by individual workers, ${ }^{3}$ the amount produced, ${ }^{4}$ the labour power or capacity of individuals, ${ }^{5}$ the type of work or employment ${ }^{6}$, the product of work, qualitatively and quantitatively. ${ }^{7}$ In a sentence like: "But in consequence of

1 The lexical ambiguity of the words labour and work resists the attempt of the writer to come up with precise conceptual definitions, as one can see under the entry "Business": "Everything that is done in a Masonic Lodge, relating to the initiation of candidates into the several degrees, is called its work or labor; all transactions such as are common to other associations and societies come under the head of business, and they are governed with some peculiar differences by rules of order, as in other societies." (Mackey 1914, 125).

2 "In those great manufactures, on the contrary, which are destined to supply the great wants of the great body of the people, every different branch of the work employs so great a number of workmen that it is impossible to collect them all into the same workhouse" (Smith 1999, 109). In chapter VI, "Of the Component Parts of the Price of Commodities", work, in the plural, is used to mean manufacture, and labour to mean work as a task: "In many great works almost the whole labour of this kind is committed to some principal clerk" (Smith 1999, 152).

3 "What is the work of one man in a rude state of society being generally that of several in an improved one" (Smith 1999, 111). "Secondly, the advantage which is gained by saving the time commonly lost in passing from one sort of work to another is much greater than we should at first view be apt to imagine it" (Smith 1999, 113). "Whoever has been much accustomed to visit such manufactures must frequently have been shown very pretty machines, which were the inventions of such workmen in order to facilitate and quicken their particular part of the work" (Smith, 1999, 114). "In such situations we can scarce expect to find even a smith, a carpenter, or a mason, within less than twenty miles of another of the same trade. The scattered families that live at eight or ten miles distance from the nearest of them must learn to perform themselves a great number of little pieces of work, for which, in more populous countries, they would call in the assistance of those workmen" (Smith 1999, 122). Work in this case is the same as trade or occupation, as in Chapter VIII, "Of the wages of labour", where Smith writes: "In all arts and manufactures the greater part of the workmen stand in need of a master to advance them the materials of their work, and their wages and maintenance till it be completed" (Smith 1999, 168).

4 "This great increase of the quantity of work which, in consequence of the division of labour, the same number of people are capable of performing, is owing to three different circumstances" (Smith 1999, 112). "Each individual becomes more expert in his own peculiar branch, more work is done upon the whole, and the quantity of science is considerably increased by it" (Smith 1999, 115).

5 "Every workman has a great quantity of his own work to dispose of beyond what he himself has occasion for; and every other workman being exactly in the same situation, he is enabled to exchange a great quantity of his own goods for a great quantity, or, what comes to the same thing, for the price of a great quantity of theirs" (Smith 1999, 115).

6 "But without the disposition to truck, barter, and exchange, every man must have procured to himself every necessary and conveniency of life which he wanted. All must have had the same duties to perform, and the same work to do, and there could have been no such difference of employment as could alone give occasion to any great difference of talents" (Smith 1999, 120).

"A country carpenter deals in every sort of work that is made of wood: a country smith in every sort of work that is made of iron" (Smith 1999, 122). "It is impossible there should be such a trade as even that of a nailer in the remote and inland parts of the Highlands of Scotland. Such a workman at the rate of a thousand nails a day, and three hundred working days in the year, will make three hundred thousand nails in the year. But in such a situation it would be impossible to dispose of one thousand, that is, of one day's work in the year" (Smith 1999, 122). This meaning of work as the result of productive activity also appears in chapter VI, Of the Component Parts of the Price of Commodities: "As soon as stock has accumulated in the hands of particular persons, some of them 
the division of labour, the whole of every man's attention comes naturally to be directed towards some one very simple object. It is naturally to be expected, therefore, that some one or other of those who are employed in each particular branch of labour should soon find out easier and readier methods of performing their own particular work, wherever the nature of it admits of such improvement" (Smith 1999, 114), labour and work are almost synonymous, since division of labour consists in parcelling work.

In chapter VII, "Of the Natural and Market Price of Commodities", labour is defined as "work to be done", whereas commodities are "work done"8. In chapter VIII, "Of the Wages of Labour", work means production, and labour means the use of labour power: "Let us suppose, for example, that in the greater part of employments the productive powers of labour had been improved to tenfold, or that a day's labour could produce ten times the quantity of work which it had done originally" (Smith, 1999, 167). But in the same chapter, the wages of "labour" are equated with the price of "work": "The former [wage workers] are disposed to combine in order to raise, the latter [employers] in order to lower the wages of labour. [...] We have no acts of parliament against combining to lower the price of work; but many against combining to raise it" (Smith 1999, 169). And, still in the same chapter, work means waged employment: "A man must always live by his work, and his wages must at least be sufficient to maintain him" (Smith 1999, 170).

The distinction between work and labour becomes sharp when Smith's focus is on labour as the measure of (exchange) value, as in chapter V, "Of the Real and Nominal Price of Commodities, or their Price in Labour, and their Price in Money":

The real price of everything, what everything really costs to the man who wants to acquire it, is the toil and trouble of acquiring it. What everything is really worth to the man who has acquired it, and who wants to dispose of it or exchange it for something else, is the toil and trouble which it can save to himself, and which it can impose upon other people. What is bought with money or with goods is purchased by labour as much as what we acquire by the toil of our own body. That money or those goods indeed save us this toil. They contain the value of a certain quantity of labour which we exchange for what is supposed at the time to contain the value of an equal quantity. Labour was the first price, the original purchase-money that was paid for all things. It was not by gold or by silver, but by labour, that all the wealth of the world was originally purchased; and its value, to those who possess it, and who want to exchange it for some new productions, is precisely equal to the quantity of labour which it can enable them to purchase or command. It is difficult to ascertain the proportion between two different quantities of labour. The time spent in two different sorts of work will not always alone determine this proportion. The different degrees of hardship endured, and of ingenuity exercised, must likewise be taken into account. There may be more labour in an hour's hard work than in two hours' easy business; or in an hour's application to a trade which it cost ten years' labour to learn, than in a month's industry at an ordinary and obvious employment. But it is not easy to find any accurate measure either of hardship or ingenuity. In exchanging, indeed, the different productions of different sorts of labour for one another, some allowance is commonly made for both. It is adjusted, however, not by any accurate measure, but by the haggling and bargaining of the market, according to that sort of rough equality which, though not exact, is sufficient for carrying on the business of common life" (Smith 1999, 134).

What we can see here is that, while the lexical fuzziness persists (mark the presence, in this paragraph, of synonyms like "business", "employment", "industry"), a conceptual distinction is

will naturally employ it in setting to work industrious people, whom they will supply with materials and subsistence, in order to make a profit by the sale of their work, or by what their labour adds to the value of the materials" (Smith 1999, 151).

8 "Such fluctuations affect both the value and the rate either of wages or of profit, according as the market happens to be either overstocked or understocked with commodities or with labour; with work done, or with work to be done" (Smith 1999, 162).

${ }^{9}$ This could be related to the practice of paying craftsmen, as opposed to journeymen, by the piece and not by the day. 
made between (what Marx would call concrete) work producing real things as use values and involving a concrete experience ("hardship") and (what Marx would call abstract) labour generating exchange values, which can be measured ("proportion of quantities"), thanks to the "higgling and bargaining of the market". Here work and labour cannot be used interchangeably. Once labour has thus been opposed to work, Smith is able define capital as "a certain quantity of labour stocked and stored up to be employed", a definition taken up by Marx in the 1844 manuscript. After Smith, English political economists such as Malthus (1814) and Ricardo (1821) used exclusively the word labour in relation to exchange value, whether they disagreed (Malthus) or agreed (Ricardo) with Smith. It is this conceptual distinction that Engels seemed to apprehend as a lexical distinction in English. By forcing these exclusive conceptual meanings into the lexically polysemic English words labour and work for the purpose of clarity, he himself created a subtext for Marxists that separated them from non-Marxists, unwillingly creating an obstacle to discussion. Attempts at distinguishing between labour and work by looking at etymology, identifying labour with something painful and linked with both exploitation and alienation while work would be related to man's quintessence and related to freedom and happy self-expression, cannot adequately account for the original conceptual distinction that we find to be born with Adam Smith: in the above mentioned conceptually decisive passage, it is "work" that is linked with hardship and pain, not "labour". Hardship and pain can only exist in the actual experience of working. While exploitation (extracting surplus from actual work to maximize and appropriate the resulting labour value) does increase the level of hardship involved, while alienation does simultaneously increase (by dehumanizing) and lessen (through ideology) the feeling of hardship, there is an irreducible aspect of pain involved in actual work, which is also associated with a feeling of pleasure, but that is another story. When labour is "purchased" and "commanded", then the "toil and trouble" of work is shifted from employer to employee.

Thus, the study of Marx's subtext helps us clarify the work/labour controversy, by ascertaining its character, i.e. a conceptual distinction between two aspects of work/labour. In the course of that enquiry, we have seen the variety of words used to refer to work/labour in the English language, the richness of their connotations in various contexts, and the polysemic character of the word work itself. Both the number of work/labour related words and the very polysemic of the word work itself invite us to pursue the enquiry in the direction of linguistics. What can we learn from a study of the various words that are used to express work/labour, in English but also in other languages? What does this polysemy tell us about the important dimensions of work/labour for human beings, an importance that is reflected in their nomination of work/labour? To answer these questions, we must turn to cognitive linguistics.

\section{The Contribution of Cognitive Linguistics}

The founding hypothesis of cognitive linguistics, born with Ronald Wayne Langacker (1973), is that "our ordinary conceptual system, in terms of which we both think and act, is fundamentally metaphorical in nature" (Lakoff and Johnson 1980, 3] ${ }^{10}$. In a metaphor, the relationships between elements of a source domain are viewed as similar to those prevailing in the target domain, which enables the speaker to use words from the source domain to describe relationships in the target domain. Lakoff and Johnson's classical example is the metaphor "love is a journey", where "journey" is the source domain and "love" is the "target domain". There are several characteristics of a journey that are similar to those of an amorous relationship (beginning, duration, end, purpose, ups and downs, twists and turns, etc.). This analogy between love and a journey enables people to say, for example, that their relationship is at a crossroads. Jacques Lacan (1957), developing Freud, has related the metaphor

\footnotetext{
${ }^{10}$ This method has fruitfully been applied to contemporary debates on issues directly related to the relationship between digitalized work and property by Steve Larsson in his article on "The Conceptions of Copyright in a Digital Context: A Comparison between French and American File-sharers" (Larsson 2014).
} 
to the unconscious process of condensation (Verdichtung), where two signifiers are superimposed.

When Shakespeare writes of Love's Labour's Lost, or when I say that I'm working on a steak, the realm of work/labour is the source domain of the metaphors and love, or eating, are the target domains. The omnipresence of work/labour in our lives, its centrality, make this particular source domain available for a myriad of metaphors in a host of target domains. The ever-growing commodification of everything makes it necessary for workers to sell their labour power to obtain access to nature's untransformed bounties, such as a fresh breeze of clean air or a drop of pure water, silence or an unspoilt landscape. The appropriation by capitalists of the exchange value generated by activities not designed for the purpose of creating exchange values, as we can see in data mining, give these activities the character of unpaid labour, as prosumers and social network users realize that their activity is profitable to others and start demanding compensation for something they were doing for free, thereby accepting the commoditization of whole aspects of their private lives, which now look like work/labour to them. The exaltation of a hard-working ethos, whether it is salaried work (viz. the stigma attached to unemployment) or working out in a gym point to the internalization of the demand made by capital that every human being maximizes his or her productive effort, whatever the circumstances, and the word work ends up encompassing all human activities that can directly or indirectly be turned into a profit.

All the words denoting labour or work are abstractions, since they put together various activities, which, viewed concretely, bear another name: to dig a hole, cut a piece of metal, fish, hunt, clean, put things in their proper place, write, etc. The question is thus: what do these activities have in common that they should be called work or labour, and from which angle is the similarity perceived? For we know very well that fishing, writing, driving, building a table, etc. can be called either work/labour or play under different circumstances. Harry Cleaver (2002) has suggested that since the work/labour concept was born with modernity and the rise of capitalism as a "capitalist category", we should not use it for previous periods. He certainly has a point, whether we are discussing labour as the all-encompassing word for surplus value generating activities, or work as the all-encompassing word for purposeful human activities in the wake of the Reformation, as Max Weber (2010) has shown. But historicization should be carried further back, since the words work, labour, and their equivalents in all languages did exist before their extended and often metaphorical meanings in modern times.

A genealogical, etymological investigation is certainly in order, with the caveat that some etymologies can be deceptive. For instance, in Russian, the word trud (труд), based on the Indo-European root treudō (v. Sanskrit tard, Latin trudo), meaning painful effort, applies both to hard labour, ascetic pursuits of monks and [...] academic publications (well, not that deceptive in the end!). In the course of that etymological investigation, one question has emerged: what is the cognitive linguistic process that has resulted in the invention of the words that denote work/labour? And the answer is that all the words denoting work/labour are metonymies, often coupled with metaphors.

A metonymy, according to the Oxford English Dictionary, is "a figure of speech which consists in substituting for the name of a thing the name of an attribute of it or of something closely related" (OED Online, 2013). In traditional rhetoric, three types of metonymies are distinguished: whole for part, part for whole, and part for part. In cognitive linguistics, there is an ongoing debate on whether metonymy is a sub-category of the metaphor, or whether it is the opposite pole of the metaphor, but this debate will not be dealt with here. Cognitive linguistics distinguishes between two types of metonymy, source-in-target metonymy, and target-in-source metonymy. Source-in-target metonymy consists in using a word that is a part ("source subdomain") of what one wants to represent ("target domain"): in the phrase "all hands on deck", hands ("source subdomain") are a part of sailors ("target domain") that "stands for" sailors. It involves "domain extension", in the sense that they provide access, from the subdomain, to the full concept or "matrix domain" (Ruiz de Mendoza 2000, 109132). Target-in-source metonymy consist in using the wider domain as source to refer to the subdomain, as in "I'm tying my shoes", while what I am actually tying is a part of my shoes, the laces. In this case, cognitive linguists speak of domain reduction, drawing attention to the 
"salient" feature of what one wants to represent in the context. I tie my laces because I want to use my shoes, so I can use the metonymy, because the focus is on the shoes, not on the laces, which are a means to an end. If my laces are broken, the focus will be on the laces, and I will not be able to use a metonymy by saying "I need new shoes". Lacan (1957) relates the metonymy process with the other fundamental unconscious process that is displacement (Verschiebung), in which the emotional charge of the original signifier is transferred to another signifier, which is made possible by their contiguity.

The French word travail, like the Spanish trabajo comes from Latin trepālium, an instrument of torture. It was formed by metonymy first: the part of the work experience that is the repetition of the pain inflicted on the worker by the work process is the "salient" part (the subdomain that stands for the whole domain); then a metaphorical process occurs, involving analogy: it is an experience similar to torture, and then the metaphor of a torture instrument can be used to name it. In the same way, when going to work to, say, an office job, some French speakers, notably of working class origins, ${ }^{11}$ will jokingly use the phrase "je pars à la mine" ("I'm going to the mine") as the salient part of their prospective workday is hardship (metonymy) and miner's work is the archetype of hardship at work (metaphor). The same French speaker would also say at the same point in the morning "je vais à la boîte chercher de la galette": I'm going to the (slang for) company worksite to get (slang for) money, here stressing the necessity to be employed that is related with proletarian status.

While metaphors such as trepālium are interesting, it is way too late to understand the precise circumstances that led to their use in the first place, and the reasons for the success they met. On the other hand, one can easily reconstruct the original metonymy, which sheds light on the "salient" characteristic of work/labour that was perceived as salient by the speakers. More difficult to find out is in what class of society the metonymy originated with, an avenue of research that is promising, and could be explored by looking at the lexicon of selected subcultures. No Frenchman without connections with the working class would use the mine metaphor. In the end anyway, the whole of society adopts a common stock of metonymies and metaphors to build a national language.

What we propose to do here is to explore and classify the types of metonymies that have made up the lexical field of work/labour in several languages, with the hope of discovering useful conceptual distinctions. Only a small part of the languages spoken by human beings on the planet across the ages are under study, and none is given a complete treatment. In particular, I could not access the languages of so-called "primitive" (i.e. non-literate) societies, which must be of particular interest. There is a lot of work to be done to verify the generalizations I arrived at in this research. Restricted as it was, my field of investigation extended far beyond my linguistic competences, and I am very grateful for the help received from friends and colleagues.

\section{Founding Metonymies and Related Metaphors}

I have found six types of metonymies at the origin of the words denoting work/labour in the languages under study ${ }^{12}$ :

\footnotetext{
${ }^{11}$ The example comes from personal experience with my first father-in-law, who graduated from Lumpenproletariat origins to metallurgy worker to office worker and was a prominent labour activist but still used the lexicon of his original subculture.

12 There might be a seventh one, based on the performance of discrete tasks to which one is compelled by necessity, linked with the precariousness of employment and/or of subsistence. In English, the word job meaning "a piece of work; esp. a small definite piece of work done in the way of one's special occupation or profession" is said by the Oxford English Dictionary to be "of obscure origin: prob. in colloquial use some time before it appeared in literature. Possibly connected with prec., sense 2" [i.e. A cart-load, or what a horse and cart can bring at one time], itself obviously connected to the first sense: "a small compact portion of some substance; a piece, lump; a stump, block; a tassel", possibly originating in Old French gobe, goube a mouthful, lump, etc., possibly from Gaul gob. A similar word is gig, an engagement for a musician. The Chinese 活 huo, to live, living, life, also means work, job, in colloquial Chinese, what "keeps body and soul together" as in the French "gagne-pain" (what serves to earn one's bread), that is what provides the means of life. Associated with 农 nong, farm, 农活 nonghuo
} 
- 4.1. Denoting activity

- 4.2. Denoting effort, difficulty, pain

- 4.3. Denoting the result or product of activity

- 4.4. Denoting torture

- 4.5. Denoting status of workers

- 4.6. Based on one particular activity

\subsection{Denoting Activity}

This is the original metonymy for the origin of the English word "work", a case of target-insource metonymy involving domain reduction, from activity in general to a particular type of activity, work. One of the oldest available occurrences of the word work in Old English, Beowulf 287 B9, circa A.D. 1000, is clearly referring to action, deeds, as opposed to words (praxis or poiesis as opposed to lexis): "gescad witan, worda ond worca, se pe wel penceð.." ("A keen-witted shield-bearer who thinks things out carefully must know the distinction between words and deeds, keep the difference clear") (Chickering, 2006, 64-65).

The root is the proto-Indo-European word Wergom, hence the Indo-Eupanobueg ug -, denoting activity. It resulted in ergon ("̌pyov), organon (öpyavov) in Greek, weorc or worc in Old English, Werk in German, gwreith in Middle Cymric, etc. ${ }^{13}$ Analyzing this passage of Beowulf, Peter Clemoes $(2006,158-161)$ refers this language to the Germanic legal tradition, detailing the obligations of a person to his lord, not only words, but also acts, deeds. Thus even the most abstract form of the concept (action as opposed to inaction, movement as opposed to inertia-as in the definition of (mechanical) work in physics introduced by the French physicist Coriolis in 1826 under the name travail, translated as work in English and Arbeit in German-or activity opposed to repose) was entangled in the web of social relationships when it appeared in English. The original notion of work in English could therefore

means farmwork. Pending further research in other languages, and considering that no verbs are associated, this notion is best left in a footnote for the time being.

${ }^{13}$ Podkorny's entry, p. 988, adapted, with the abbreviations developed and translated into English:

uĝ -2, Lê̂ -

English meaning: to do, work

German meaning: wirken, tun

Deitä : :Lệmilek

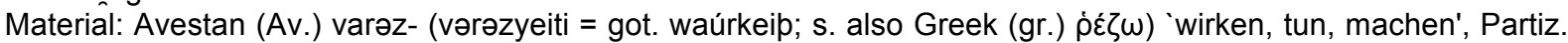
varšta-, varəza- m. 'Wirken, Verrichten von, Tätigkeit' (npers. varz, barz 'Feldarbeit, Ackerbau'), varšti- f. 'Handeln, Tun', varštva- Adj. 'was zu tun ist'; Armeinian (arm.) gorc 'Werk' (mit sekundärem o); Greek (gr). हैpyov,

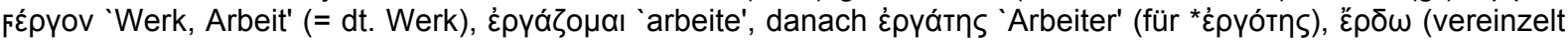

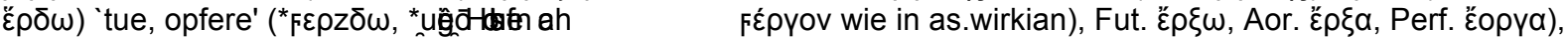

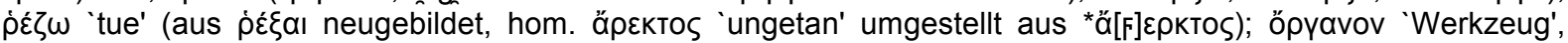

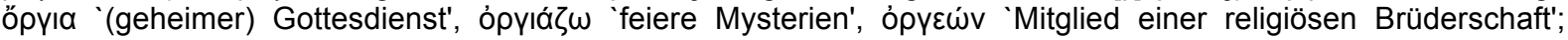

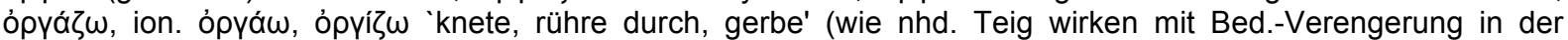
Berufssprache), wozu ćópyn 'Quirl' (wohl redupl. ₹E-Fópyā); alb. rregj 'reinigen', Mediopassiv rregjem 'mühen, streben' (St. E. Mann Lg. 26, 382 f.); Old Breton (abret.) guerg 'efficax', Gallic (gall.) vergo-bretus 'oberste Behörde der Aeduer', auch verco-breto (Pokorny, Vox Romanica 10, 266 f.); Middle Cymric (mcymr.) gwreith 'Tat' (đ̛̣ $\hat{g}$-tu-), 1. Pl. Imper. acymr. guragun, jünger gwnawn usw. (n statt r durch Einfluß von *gnī- 'machen', S. 373), Cornish (corn.) gruen, mbr. gr-(uepr đa r $\hat{g}$ - 'machen'), Lewis-Pedersen S. 336 f.; as. wirkian (Neubildung nach werk), warhta, High old German (ahd.) Frankish (fränk.) wirkan, wirchen, war(a)hta `arbeiten, tätig sein, wirken'; got. waúrkjan (= av. vərəzyeiti), aisl. yrkja, orta, ags. wyrcan, worhte, ahd. (obdt.) wurchen, wor(a)hta 'wirken, tun, machen, bewirken', ahd. gawurht f. 'Tat, Handlung', got. frawaúrhts 'sündig', f. 'Sünde' usw., got. waúrstw n. 'Werk' ('waúrh-stwa-; ähnlich av. varštva-); High old German (ahd.) werc, werah, Anglo-Saxon (as) werk, aisl. werk n. (= ع̋pyov) 'Werk, Tätigkeit, Arbeit' Anglo-Saxon (as.) weorc auch 'Mühsal, Qual', weshalb auch Old Icelandic (aisl.) verkr, Genitive verkjar (m. i-St.) 'Schmerz, Leid' hierhergehören kann; High old German (ahd.) wirken 'nähend, stickend, webend verfertigen' = as. wirkian, ags. wircan, und das davon nicht trennbare High old German (ahd.) werih in der Bed. 'Werg, stuppa', āwirihhi, āwurihhi 'Werg' zeigen Anwendung unserer Wz. auf die

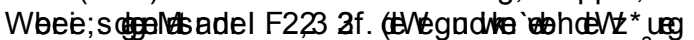

- 'drehen, winden' zuteilen möchte); an nhd. Werg erinnert Cymric (cymr.) cy-warch 'Hanf, Flachs' = Breton (bret.) koarc'h, Olf Breto ( et ) calting. c̀maina; -k- 'drehen'. 
be related with obligation by a third party: there is no reason why the words that are the equivalents of "work/labour" in other languages would not have appeared at the same moment as servitude: fishing, hunting, gathering, cooking, etc., were activities with names of their own, and there was no reason to lump them together under the heading "work" before work was imposed on people by their masters. More on this anon. In Wolof, the word ligeey, to be active, is the same as to be at work, and also employed, and its opposite, tok, which means to sit, is the word used for the status of unemployed.

The notion of activity also predominates in the Russian zanimát'sja (замиав в ), to busy oneself (when studying, doing sports, etc.). In sign language, as a source-in-target metonymy, "activity" is signed in the same way as work (see infra), with only the mouthing differing. In Lingala, mosálá, to work, is the same as to do. In standard Arabic, one of the two words meaning "work" similarly carries primarily the notion of activity, "to do": fa3ala/yaf3alu (ف) / (ف) (ف) $)^{14}$. Interestingly, this word exists only in standard Arabic, the language developed from classical Arabic in the early $19^{\text {th }}$ century, and appears in the various dialects only as variations borrowed from the standard Arabic. As early as the $8^{\text {th }}$ century, the Arab grammarians chose to use it as the root (in its graphic aspect, as opposed to the phonetic aspect) to represent the morphologic schemes of the Arabic language. Thus, the word kātib (الكاتب), writer, is viewed by the grammarians as following the fā3il scheme. One is reminded of Hannah Arendt's remarks on the birth of rhetoric as the substitution of persuasion for violence at the birth of the polis, with the separation of words from deeds (which were coupled in heroic times) (Arendt 1998, 25-26), except that written words are the words involved here. A keenwitted shield-bearer who thinks things out carefully must indeed know the distinction between written and spoken words on the one hand and deeds on the other hand, keep the difference clear, and also see the social relationships that connect them.

\subsection{Denoting Effort, Difficulty, Pain}

In many languages, the notions of effort, difficulty and pain are present in the lexicon of work, and most of the time these salient characteristics are present together in the same words, with only the context pointing to one separate characteristic. Only in Wolof (but there must be other examples) could I find two words for "to work", one of which does imply effort, but not necessarily painful effort. Should this distinction be found to exist in other languages, the present section would need to be divided in two and the typology extended.

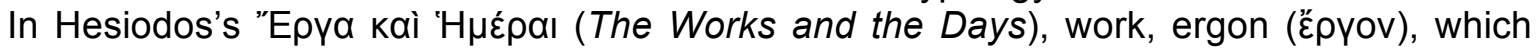
does imply effort, but not necessarily painful effort, is first introduced as a valued activity motivated by envy of another man's wealth. It is part of human nature, and, even in the Golden Age (before Zeus punished Prometheus for stealing the gods' fire by sending them Pandora and her box) men satisfied their needs through work, the difference with the later ages being

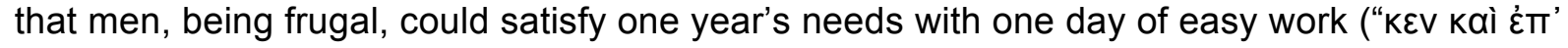

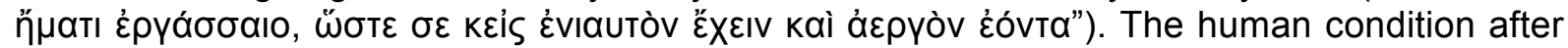
the Golden Age is characterized by the addition of ponos (móvos) painful and difficult work

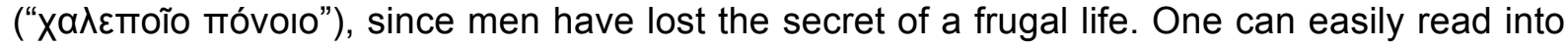
the fable the Marxist concept of surplus work/labour demanded by masters and refer the causes of the existence of surplus work/labour to domination rather than Pandora's myth.

Among the meanings of ponos (móvos), we find hard work, toil, as in toil of battle, trouble, bodily exertion, exercise, stress, trouble, distress, suffering, pain, especially physical-

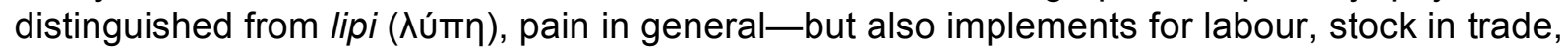
task, business, enterprise, undertaking. While the original metonymy was a target-in-source metonymy involving domain reduction (from the painful aspect of work to hard work in general), it gave rise to the opposite, source-in-target metonymy involving domain extension (from the work experience, seen as painful, to the notion of enterprise, and even anything

\footnotetext{
${ }^{14}$ fa3ala / yaf3alu: he did, he does (there is no infinitive form in Arabic). The scheme is fā3il.
} 


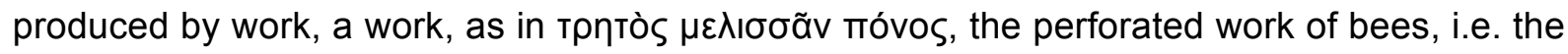
honeycomb in the poetic language of Pindarus.)

The Indo-European root of the Greek word ponos (móvos) is (s)pend, ${ }^{15}$ which seems to relate to the pulling motion that comes with spinning and weaving (from the same the root "spend"). The painful experience of women spinning and weaving seems to have been at the origin of the word. Another painful experience, that of carrying heavy loads, has been at the origin of the Latin word labor (labor, lapsi, lapsus sum) which has given the French labeur and labour (ploughing), the English labour, the Italian lavoro, etc. The meaning of the Latin labor is to slip (as in lapsus, a slip of the tongue), under a heavy burden. The same reference to a heavy burden can be found in the Russian language, which has two words for work: trud (труд), and rabota (работа), close to rabotsva (рабства), meaning slavery (see infra 3.5). Trud (труд) belongs to the group of words denoting pain, together with the Latin trūdō (to thrust, push, shove; to crowd or shove forward; to press on, drive, impel), both rooted in Indo-European tr-eu-d-, to press, to squeeze, like under a heavy burden. ${ }^{16}$ It is the word used

${ }^{15}$ Podkorny's entry, p. 988, adapted, with the abbreviations developed and translated into English: (s)pen(d): to pull; to spin, 'ziehen, spannen' und 'spinnen', indem die zu webenden Fäden zuerst ausgespannt wurden.

General comments: (s)pen- : spē(i)- 'ziehen' = pen- 'füttern': pā- 'Vieh weiden, füttern' \{to graze cattle, to feed\} =

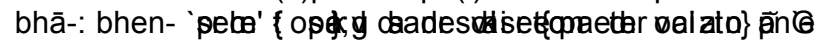
oben $\{$ see above $\}$ S $\{\mathrm{p}\} .788$.

Material: 1. Formen ohne -s-

Armenian (Arm.) hanum, aorist (Aor.) hanay und henum, aorist (Aor.) heni 'weben, zusammennähen'; s. darüber

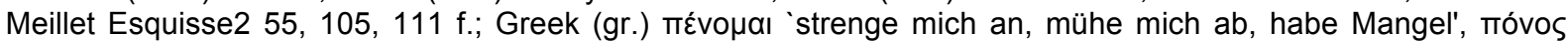

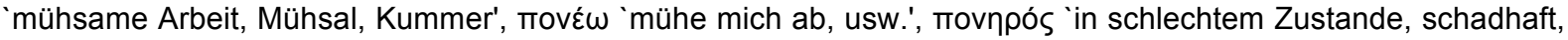

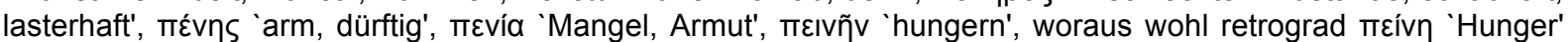

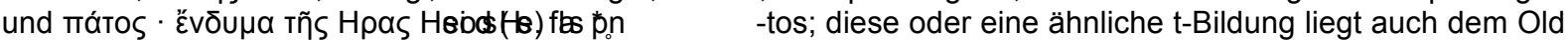
Irish (air.) ēt- 'kleiden' zugrunde; Lituanian (lit.) pinù, pìnti ‘flechten', pántis m. f., Old Prussish (apr.) panto f. 'Fessel', Latvian (lett.) pinu, pît 'flechten', pinekls 'Fessel'; Old Church Slavic (aksl.) pbnǫ, pęti ‘spannen', (ablaut.) opona f. 'Vorhang', ponjava 'Umhang, Kleid', pǫto `Fessel'(serb. püto), wozu Old Russian (a.russ.) prepjátb 'hindern', raspjátb 'kreuzigen', pjatb, pnutb 'mit dem Fußestoßen' und Old Church Slavic (aksl.) pęta 'Ferse' Serbian (serb.) petasati 'mit den Füßen ausschlagen'), Russian (russ.) pjatá, Serbian (serb.) péta, Lituanian (lit.) péntis m. 'ds.; Rücken der Axt, der Sense', Old Prussish (apr.) pentis 'Ferse'; vielleicht Albanian (alb.) pendë, pëndë 'Paar Ochsen; Joch (Ackermaß)' aus einem *pentā ‘*Gespann'; auch penk 'Koppel';

2. Formen mit anlaut. s-: Latin (lat.) sponte `aus eigenem Antrieb, aus freiem Willen', Gothic (got.) Old High German

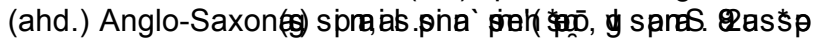
-nuфळ+b

German (ahd.) spinna 'Spinne'; mit einfachem n: Old Icelandic (aisl.) spuni m. 'Gespinst', Anglo-Saxon (ags.) spinel, Old High German (ahd.) spinala (und spinnila) 'Spindel'.

3. Erweiterung (s)pen-d-:

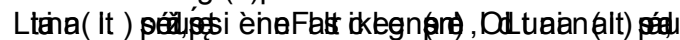

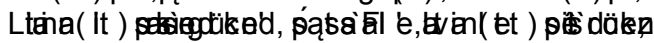

-yti 'spannen', spuôsts 'Fallstrick, Falle', Latvian (lett.) spendele 'Feder an einem Schlosse', spanda 'Strickwerk am Pflug', wie

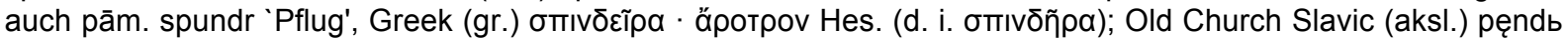
'Spanne', pǫditi 'drängen, treiben' (ursprüngl. etwa 'ein Vieh an gespanntem Strick vorwärtsziehen'); vermutlich auch als 'gespannt hängen', Latin (lat.) pendēo, -ēre 'hangen, herabhangen', pendō, -ěre 'wägen, schätzen, zahlen' (zum Wägen aufhängen), Umbrian (umbr.) ampentu 'impenditō'; ob auch Anglo-Saxon (ags.) finta m. 'Schwanz, Folge'?

${ }^{16}$ Podkorny's entry, p. 1095, adapted, with the abbreviations developed and translated into English: tr-eu-d-

English meaning: to press, push

German meaning: 'quetschen, stoßen, drücken'

General comments: wohl Erw. zu ter-3, tereu- 'reiben'

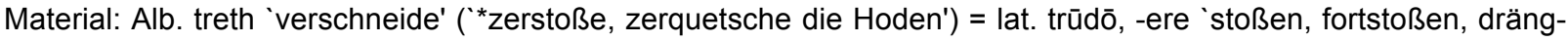
en' (trūdis 'eisenbeschlagene Stange zum Fortstoßen'); mcymr. cythruð 'quälen', godruð 'wild', gorthruð 'Bedrückung' ("-treudo-); mir. trotaid 'streitet' (*truzd- aus *trud-d-), cymr. trythill, drythill 'wollüstig' (daraus mir. treitell 'Liebling'); air. tromm, cymr. trwm 'schwer' ('trudsmo- 'drückend'); got. uspriutan 'beschwerlich fallen', aisl. prjōta 'mangeln', ags. (ā-)ðrēotan unpers. ‘ermüden, überdrüssig werden', ahd. (ar-, bi-)driozan 'bedrängen, belästigen', nhd. verdrießen; aisl. prjōtr 'widerspenstiger Mensch', ahd. urdrioz 'Verdruß'; aisl. praut f. 'Kraftprobe, Bedrängnis', ags. đrēat m. 'Gedränge, Gewalttätigkeit, Drohung', mhd. drōz 'Verdruß, Last, Beschwerde' (= slav. trudъ); ags. đrēat(n)ian 'drängen, quälen, schelten, drohen'; ags. đrīetan 'ermüden (tr.), drängen', aisl. preyta 'Kraft aufwenden, aushalten, ermüden (tr. und intr.)'; aisı. prȳsta, ahd. ðrūstit, ags. geðryscan 'bedrücken', ðrysman 'erdrücken, ersticken', mnd. drussemen 'erdrosseln, erdrücken'; aksl. trudъ 'Mühe', truždǫ, truditi 'beschweren, quälen'. 
by Orthodox monks to translate into Old Slavic the Greek word ponos (móvoऽ), and also the words kopos (ко́тоऽ), pain, here a self-inflicted blow to the chest (in the context of asceti-

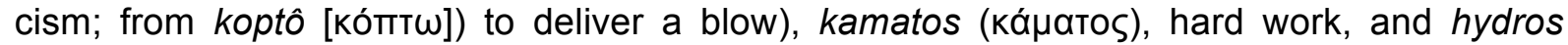

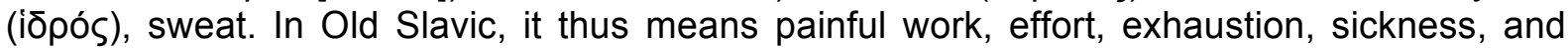
also difficulty. The reference to sweat is also to be found in the original curse, "by the sweat of thy brow", but also in Wolof, where painful work is called niax jariñu, niax meaning sweat, and jariñu meaning useful. Another Wolof word for "to work", daan dole, meaning to use one's strength (dole) puts more stress on the notion of effort than on the related pain. This brings to mind the notion of energy, its physiology, and what Freudians call the psychological economy of the libido.

The adjective formed on trud is used to denote the particularly difficult characteristic of one type of work, as in trudnaja rabota (трудная работа), hard and painful work. But the word becomes dignified when used by monks, extolling their own ascetic and associated intellectual pursuits and later communists, when trudjaschiesja (трудящиеся) became the official word for the supposedly dominant working class. There is even an organization ${ }^{17}$ in Russia entitled "Workers against slavery", Trudjaschiesja protiv rabotsva (Трудящиеся против рабства), under a banner inspired from the French Socialist Party logo. While the original metonymy was a target-in-source metonymy involving domain reduction (from the painful aspect of work to hard work in general), it gave rise to the opposite, source-in-target metonymy involving domain extension (from the work experience, seen as painful, to the notions of cultural production, dignified group).

The painful connotation is present in the standard Arabic 'amal (a) ), which resulted in the Swahili amali, pointing to colonization and slave production in the area.

The sinogram 劳 lao denotes painful work. According to the etymological dictionary Shuōwén Jiězì (說文解字), made available in $121 \mathrm{AD}$, and reflecting the specular turn of mind prevailing under the Hans, the original sinogram, in the xiaozhuan (Small Seal Script (小管, 221-207 BC) is the superposition of 火火 the night light (fire) at the top, $\neg$ the roof in the middle, signifying the hose, and 力 force, in the bottom. Rooted in lao, we find 劳人 laoren (lao + ren [man]) hard worker, 劳力 (lao + li [strength]) to perform manual work, 劳神 laoshen (lao + shen [mind]) to think hard, intellectual fatigue. Associated with 动 dong, denoting movement, we find 脑力劳动 naolilaodong (nao [brain[ + li [strength] + lao + dong), intellectual work, 体力劳动 tillilaodong (ti = body), manual work, but also 劳动法 laodong+fa (law), labour law, and 劳动合同 laodong + hetong (contract), work contract.

The painful characteristic of work has resulted in labour referring to birth giving (travail in French), which is in fact a combination of two source-in target metonymies, one stressing the painful character of both processes, the other one emphasizing, in both cases too, the result of activity (something is produced, see infra 3.3) therefore inviting comparison and leading to the creation of the metaphor, long before it became part of the Marxist feminist notion of reproductive labour as reproducing labour power. It was obviously sourced in the Christian tradition, since there is no such use of the word labour or its equivalent in Hebrew to denote childbearing, although the original curse in Hebrew refers to pain (itstsabon, עיכָּבון) both for the woman's experience of childbirth and the man's experience of tilling the ground). The English language has appropriated the French word travail, to designate all sorts of painful experiences, including travel before the days of package tours.

Some degree of pain is unavoidable when "grappling with reality", the working subject is engaged in a struggle against the object that is worked on, hence the metaphor of battle, in the English word toil, which originally meant argument, strife, battle.

\subsection{Denoting the Result or Product of Activity}

\footnotetext{
${ }^{17}$ http://sd-inform.org/biblioteka/antitotalitarizm/trudjaschiesja-protiv-rabstva, accessed January 10, 2014.
} 
In the Latin family of Indo-European languages, the concrete product of work receives names based on the Indo-European root $\mathrm{Op}^{18}$ : Latin opus, French œuvre, Spanish obra, Italian opera, etc. The process that leads to the creation of these works, concrete work, is called operare (Latin, Italian) œuvrer (French, also ouvrage, both the result of work and the work process), obrar (Spanish), etc. And the individuals involved in the process of producing such objects, the workers, are called ouvriers (French), operai (Italian), obreros (Spanish), etc., a particular class of waged workers that produce material goods outside agriculture (but the concept can be extended to agricultural waged work as in the French ouvrier agricole, with a modifier).

A first metonymy projects the result of work onto the work process, another one projects the work process onto the worker, a third one can project it on the end result. The French labourer (to plough), originating in Latin labor (see supra) gives labour, as the activity ("faire les labours" = labourer, to plough) of the laboureur (ploughman) and the result of the activity ("marcher dans les labours", to walk through ploughed fields).

An opposite process can be observed in English, in which the activity gives its name to the result of activity, especially for intellectual work (works of art, good works in the language of religion) or in German (Werk). In Russian, the word trud (труд), denoting painful and difficult work, gives its name to the resulting work of the mind, as in Труды Математического Института имени В. А. Стеклова, Trudy Matematicheskogo Instituta imeni V. A. Steklova, for a mathematical journal, and in Hebrew, where, most interestingly melâ'kâh (מלאכה), free labour (see infra 3.5) also means the result of work, property, thereby anticipating by a few centuries or millennia the Lockean theory of property founded on labour (Locke 2000, 298299)..$^{19}$

\subsection{Denoting Torture}

In the Latin family of Indo-European languages, French (travail), Spanish (trabajo) Provençal (trebalh), Portuguese (trabalho), Italian (travaglio) originate in trepālium (Latin), a torture instrument. The connection points to pain that does not stop, as a consequence of a minute

${ }^{18}$ Podkorny's entry, p. 780, adapted, with the abbreviations developed and translated into English. op-1

English meaning: to work, perform

German meaning; arbeiten, zustande bringen; Ertrag der Arbeit, Reichtum

Derivatives: op-os- 'Werk 'Material: Old Hindic (ai.) ápas- n. 'Werk' (= lat. opus), Avestan (av.) hv-apah- 'gutes Werk (verriheф̆ ấpa - n. 'Werk, religiöse Handlung'; ápnas- n. 'Ertrag, Habe, Besitz', av. afnah-vant- 'reich

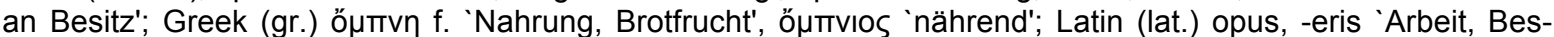
chäftigung, Handlung, Werk', opus est 'es ist nötig' ('`ist Mußarbeit'), wovon operō, -āre 'arbeiten', Oscan (osk.) úpsannam 'operandam', upsatuh sent ('factī sunt'), Perf. upsed 'fecit', uupsens 'fēcērunt', (dehnstufiges Perf. wie in lat. ōdī), Umbrian (umbr.) osatu 'facitō', pälign. upsaseter 'fieret'; lat. ops, opis 'Vermögen, Reichtum, Macht; Hilfe, Beistand', bei Ennius auch 'Bemühung, Dienst', officium 'Pflicht' < *opi-ficium 'Arbeitsverrichtung', Ops 'Göttin des Erntesegens', inops, cōpia ( $\left.{ }^{*} \mathrm{co}-\mathrm{opia}\right)$, opulentus 'reich an Vermögen, mächtig', wohl auch optimus 'der Beste' (eig. 'der Wohlhabendste') ; vielleicht der Name der Oscī, Opscī, 'Отাкоí als 'die Verehrer der Ops' und lat. omnis `all, ganz, jeder' ('op-ni-s); vielleicht air. somme 'reich', domme `arm' (su-, dus-op-simo -);

Anglo-Saxon (ags.) efnan, Old Icelandic (aisl.) efna 'wirken, tun'; dehnstufig Old High German (ahd.) uobo 'Landbauer', uoben 'ins Werk setzen, ausüben, verehren', nhd. üben, ahd. uoba m. PI. 'Feier', Middle High German

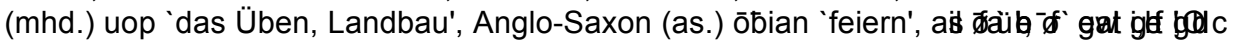
landic (aisl.) efna `ausführen', efni 'Stoff, Zeug für etwas'; über aisl. afl 'Kraft' usw. s. oben S. 52; Hittite (hitt.) happinahb- 'reich machen'.

${ }^{19}$ As expressed in chapter V of the Second Treatise on Civil Government: "44. From all which it is evident, that though the

things of Nature are given in common, man (by being master of himself, and proprietor of his own person, and the actions or Labour of it) had still in himself the great Foundation of Property; and that which made up the great part of what he applied to the support or comfort of his being, when invention and arts had improved the conveniences of life, was perfectly his own, and did not belong in common to others." The bourgeoisie was the only class in the history of Europe that both possessed means of production and performed manual work/labour, hence its special relationship to the notion of work/labour and property. But similar groups of self-employed "free" workers existed before, and could link work and the result of work sub specie of property. 
division of labour that reduces work to a repetition of the same motions for an extended period.

Marx's ideal workday, when I am able "to hunt in the morning, fish in the afternoon, rear cattle in the evening, criticise after dinner, just as I have a mind, without ever becoming hunter, fisherman, shepherd or critic" (Marx and Engels 1845/46, 53), points to a crucial characteristic of work from a eudemonistic perspective: if a change of work is a holiday, then what makes work an especially painful activity is its continuation through an over-extended period of time, the ensuing boredom, and the transformation of pain, which is an unavoidable part of life, into suffering, which is an avoidable part of life. Here, the connection with extra work demanded by masters is also present.

The repetition of the same, even innocuous per se, becomes a torment, as in the "Chinese water torture" where the pain comes from a steady dripping of water droplets on the same part of the body. And the classical image of the Fordist worker, chained to the assembly line so that he/she must repeat the same motion relentlessly, resembles that of the galley slave who does nothing but work the oars. Relentless repetition of the same is what Thanatos (the death impulse identified by Freud) is about. Relentlessness and endlessness are the two things that make hell hellish. Hell is everlasting death, as Paradise is everlasting life.

Another dimension of torture, which applies to the "Chinese water torture" concept too, is excessive focusing on one thing, the concentration involved, which is painful in itself. "In consequence of the division of labour, the whole of every man's attention comes naturally to be directed towards some one very simple object" (Smith 1999, 114).

All in all, man is living through and craving for variety, alternation and diversity. Just as we alternate inhaling and exhaling, chewing and swallowing, sleeping and waking, we need to alternate our activities. Post-Fordist human resources specialists of Internet work, who have understood this, would allow private Internet surfing (cyberloafing) to employees while at their workstation to increase productivity by lowering stress Chen and Lim 2011). This raises the issue of rhythm. Autonomous work (when I choose to work) is set to individual biorhythms, heteronomous work (when I have work imposed on me from outside, whether by necessity or violence) is set to extraneous rhythms: slaves on a galley pulling on the oars to the drum's rhythm, marching soldiers, workers on the assembly-line, Internet slaves desperately trying to catch up with incoming emails are all subject to a form of torture. In moderate doses, the extraneous rhythm energizes, as when dancing to a tune, while it becomes painful and even lethal in excessive doses, as any stimulus.

\subsection{Denoting Status of Workers: Subordination}

Heteronomous work suggests the existence of domination relationships. But, even in the absence of an actual master, the very nature of work involves a certain form of subordination. As a matter of fact, both the goal of the freely chosen work activity, and the specificities of the chosen work material themselves, impose their irreducible strangeness on the worker. When "I'm committed to my work", the goal, the end in view becomes my master, imposes a discipline, and, when I carve wood, I have to obey the dictates of the wood grain at the very moment when I transform nature. "Nature to be commanded must be obeyed" wrote Francis Bacon (Bacon 1960, 39).

In Indo-European languages, the root orbho, ${ }^{20}$ signifying orphan, bereft, servant, slave, weak child, work, has given Arbeit in German and rabota (работа) in Russian. Here, the

\footnotetext{
${ }^{20}$ Podkorny's entry, p. 780, adapted, with the abbreviations developed and translated into English. orbho-

English meaning: orphan; servant; work

German meaning: 'verwaist, Waise'; daraus Armenian (arm.) and Greek (gr.) mit -ano-, Celtic (kelt.) German (germ.) mit io-Ableitung) 'Waisengut = Erbe', wovon 'der Erbe'; 'Waise' = 'kleines Kind, klein, schwach, hilflos' (ai., slav.); 'verwaistes, schutzloses Kind, das fürs Gnadenbrot alle niedrige Arbeit zu verrichten hat, Knecht, Sklave' (slav., arm.), wovon 'Knechtesarbeit'.
} 
salient aspect of work is domination, subordination. A feeling of pity for the orphan, the weakling, resonates. Too bad human beings are subjected to this condition. Aristotle in his Politics (Ross 1957, 1253b; Davis \& Jowett 2008, 31) dreamt that one day slaves would be replaced by machines ${ }^{21}$; so did Marxist Paul Lafargue, who quoted him in his Droit à la Paresse $(1883,38)$. And Czech Karel Čapek invented the word robot (from Czech rob, slave) in his science-fiction play R.U.R. (Rossum's Universal Robots) first staged in Prague in 1921.

The Russian sluzhaschie (служащие), from the verb to serve (служить) is used for employees: hence sluzhba (служба), white-collar work. In the days of Czarist Russia, civil and military servants in the huge bureaucracy would "serve", sluzhit' (служить) rather than work (работаtь), and today's office workers, when at their workstations, are still "in service" na skuzhbe (на службе) rather than "at work" na rabote (на работе). The "noble" meaning of service, in a bureaucracy engaged primarily in intellectual and direction activities is related to feudal relations. It is comparable to the French employé, a placeholder (emploi meaning position). When a large class of waged workers appeared in the United States, the word employé was originally used, borrowed from the French, then it was anglicized into employee. In dialectal Arabic, in the Maghreb and Egypt, khedma (خد) work, is the same as service, rooted in the experience of the Arab conquest.

One of the three words denoting work / labour in Hebrew, avoda (עבוד) is similarly rooted in slavery. In Rabbinic Hebrew, it means divine worship, service (of God, originally performed by the priests in the Temple). It is a metaphor of slavery / service, since the relationship of man to god is similar to the relationship of the slave / servant (eved, עבד) to the master. In modern Hebrew, it is the most commonly used word to mean work, with the verb la'avod (לעבוד), meaning to work, the same verb used by Genesis 2.2 to describe god's work of creation (when he made himself a servant to creation [...]), [...] and gives its name to the Labour Party (Mifleget HaAvoda HaYisraelit ליתהישרא). Investigating the notion of calling (Beruf) in his Protestant Ethic and the Spirit of Capitalism, Max Weber goes at great length to make the point that the notion of calling (Beruf in German), as a service to god in worldly work, is recent, linked with the Reformation ${ }^{22}$, and that there is no equivalent in languages not affected by the Reformation. He tackles the issue of ancient languages in a footnote, where, identifying Hebrew as the only ancient language in which there is a connexion between divine service and work with the word avoda, he remarks: "Admittedly, as Professor Merx informs me, even in ancient times the Hebrew word אל had completely lost any link with the original concept [...]". "Even in ancient times", avoda must have first referred to work/labour as subordinated work, and the technical religious word must have been borrowed from the common language, not the other way round. The other Hebrew word for work / labour, melâ'kâh

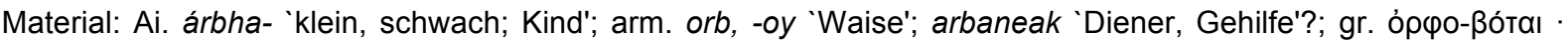

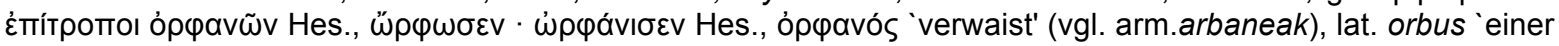
Sache beraubt, verwaist'; Old irish (air.) orb(b)e, orpe m. n. 'der, das Erbe' ( ${ }^{*} o b{ }_{0} \circ \quad-$ ), comarbe 'Miterbe', Gallic (gall.) Orbius MN (dazu das Verbum air. no-m-erpimm 'committo me', ro-eirpset `sie übergaben' usw., vielleicht aus *air-orb-), Gothic (got.) arbi n. 'das Erbe', Old high German (ahd.) arbi, erbi n. ds., Anglo-Saxon (ags.) ierfe, yrfe n. ds. Old Icelandic (aisl.) arfr m. 'das Erbe' ist zu arfi, arfa 'der Erbe, die Erbin' neugebildet), Old Icelandic (aisl.) erfi (run. arbija) n. 'Leichenmahl'; Gothic (got.) arbja, Old Icelandic (aisl.) arfi (f. arfa), Old high German (ahd.) arpeo, erbo 'der Erbe', ags. ierfe n. 'das Erbe'; die germ. Wörter stammen wegen des Folgenden kaum aus dem Keltischen; aus ein intr. Verbum *arbē-iō 'bin verwaistes, zur harten Arbeit verdingtes Kind?' führt man zurück Gothic (got.) arbaips f. 'Mühsal, Arbeit', Old Icelandic (aisl.) erfiði n. ds., as. araちēd f., arbēdi n., AngloSaxon (ags.) earfop f., earfepe n. 'Mühe, Arbeit', ahd. arabeit 'Arbeit' (aisl. erfiðr, ags. earfepe 'beschwerlich'),

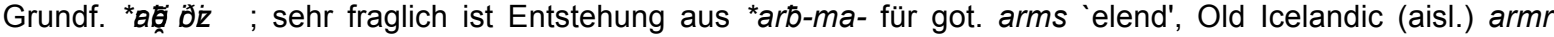
'elend, unglücklich', Old high German (ahd.) as. ar(a)m, Anglo-Saxon (ags.) earm 'arm, dürftig'; Grundbed. wäre etwa 'armes Waisenkind'; abg. rabъ 'Knecht', rabota 'servitus', Cezch (čech.) rob 'Sklave', robe `kleines Kind', Russian (russ.) rebjáta 'Kinder', rebënok 'Kind'; die russ. Formen gehen auf rob-, Old Slavic (urslav.) *orb- zurück (Vasmer brieflich); vielleicht Hititte (hitt.) arpa- 'Ungunst, Mißerfolg'.

21 "For if every instrument could accomplish its own work, obeying or anticipating the will of others, like the statues of Daedalus, or the tripods of Hephaestus, which, says the poet, of their own accord entered the assembly of the gods; if, in like manner, the shuttle would weave and the plectrum touch the lyre without a hand to guide them, chief workmen would not want servants, nor masters slaves."

As a matter of fact, in English, the word starts referring to "a trade" only in 1551, while the word calling to translate the Latin vocation appears with Wycliffe in 1382, according to the Oxford English Dictionary. 
(מלאכה), linked with artisans, handicrafts, is similarly based on the status of the worker, this time not servile: in the Old Testament, it refers to angels, ministers, i.e. employees above the rank of slaves. In Chinese, the word ye 業 (in traditional Chinese), 业 (in simplified Chinese), meaning line of business, industry, occupation, job, employment, school studies, enterprise, also means property, and, in the context of Buddhism, karma, a person's station in life viewed as the result of his/her actions. The Semitic root a.b/v.d., present in avoda, is matched by the Arabic abd (عبودية) which means servant, slave, and, by extension, worshipper as in Abdullah, servant of god.

The relationship between work / labour and slavery is sweetly expressed in the Spanish word for retirement, jubilación, which refers to the Jubilee, the biblical period, every 50 years, when slaves would be free, lands restored to their original owners and debts extinguished.

\subsection{Metonymy Based on the Gestures Involved in One Particular Type of Work}

The Chinese have three words for work/labour. One of them is gong (工). The sinogram (Chinese character) I is a stylised image of a hand-held rammer, an implement used to flatten, compact and stabilize the soil in order to build a house without foundations. Associated with other sinograms, it has given the noun 工作 (gongzuo) meaning work in general, also the verb to work, 工作者 gongzhe (gongzuo + zhe [man]) worker, 工作日 gongri (gongzuo + $r i$ [day]) workday, 工作服 (gongzuo $+f u$ [clothes]) work clothes, 工作证 (gongzuo + zheng [document]) working permit, 工人 gongren (gongzuo + ren [male]) worker, 工会 gonghui, (gongzuo + hui [meeting]) labour union, etc., and, interestingly, 工资 gongzi (gongzuo + zī [ resources, capital, to provide, to supply, to support, money, expense]), wages.

The same process (source-in-target metonymy, domain extension) has been used by the inventors of sign language for the deaf: in French Sign Language ${ }^{23}$, and in American Sign Language, which is derived from the French Sign Language, "the sign for 'work' is made by shaping both hands into 'fist shapes' [...]. With your palms facing downward, use your dominant fist to tap the wrist or the side of your non-dominant fist a few times (Memory Aid: Think of working with a hammer)": ${ }^{24}$

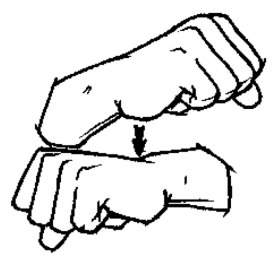

Figure 1: "work" in American Sign Language

This mimics the action of hammering, the repetition shows that there is a purpose to the activity, and the number of repetitions is left to the speaker. There is also a connotation of pain in the mutual shocks that flesh is heir to. The opposed poles of active / passive, "dominant" / subservient, subject / object are at work. The French Sign Language for unemployment ${ }^{25}$ starts very much like "work" with crossed wrists, but the hands move apart and come to rest on the hips.

In British Sign Language ${ }^{26}$ the sign for work is made with "hands held with open palms, prime hand chops down on secondary hand", as in cutting wood or meat, the upper hand functioning as an axe or chopper. "Unemployed" is signed by "Secondary hand held open

\footnotetext{
${ }^{23} \mathrm{http}: / /$ www.Isfdico-injsmetz.fr/recherche-alphabetique.php?mot=563\&lettre=t

24 http://lifeprint.com/asl101/pages-signs/w/work.htm

$25 \mathrm{http}: / /$ www.Isfdico-injsmetz.fr/recherche-alphabetique.php? mot $=920 \&$ lettre $=c \&$ valeur $=100$

26 http://www.britishsignlanguage.com/words/index.php?id=37
} 
with thumb upward. Prime hand brushes top of secondary hand", moving away from where the chopping action can be performed, showing the impossibility of chopping. ${ }^{27}$

If, like German philologists of the $19^{\text {th }}$ century, we were looking for the word work/labour in the "original language", the Ursprache, at the anthropological level, the sign languages might well point us in the right direction for "work" as a specifically human activity: the signs mimic the movement of the flint stone chopper for shaping other flint stones (Leroy-Gourhan 1964, 133-134): it is the original machine tool, the tool to make tools that makes humans human, whereas animals use tools found in nature and do not make them. Whether we agree or not in totality with the theory of The Gestural Origin of Language (Armstrong and Wilcox 2007), it seems that the Tower of Babel was built with cut stones.

\section{Conclusion}

The reasons why we use metonymies are both functional and contextual. Every object that we consider is related in our minds to a particular context and/or a particular structure, which assigns a function to the various elements which can be considered, in the last analysis, as the referents (what is signified) of any given situation. Each referent is seen as part of a whole that transcends it (irrespective of whether we have source-in-target or target-in-source metonymy) and assigns to it a function, a raison d'être (the reason why it is mentioned in the first place) within the larger situation where the referent appears. In the example "I'm tying my shoes", laces only have a function within the structural and functional scenario of a certain kind of shoe. In the case of work/labour metonymies, as in all metonymies, each metonymy is a "fractal compression" (de Oliveira e Paiva and Menezes 2010) of the web of historical and social relationships in which the referents themselves have been entangled.

It is now for us to explore in more detail the way metonymies and metaphors born along the ages from the actual experience of work/labour by our ancestors have been recycled in the Age of the Internet, as an avenue to identify the web of social relationships in which today's work situations that contribute to the existence of the Web, or connect to it in their daily course, are entangled, taking into account the salient dimensions of work/labour that linguistic inquiry has provided for further research.

Unsurprisingly, the nascent vocabulary of Internet work / labour has relied on metaphors, using existing off-line realities as a source domain to name activities in the target domain of "virtual work", which is understandable since it is a new activity which in some respects "looks like" previous activities. The "web", the "net", the "cloud" are metaphors.

But when it comes to work and labour, metonymies are back. Interestingly, writers trying to describe work on the Internet have used metonymies that were not sourced in the domain of work and labour, but in the domain of technology, specifically computer technology. Take "elancer", coined by Helen Wilkinson in 1999 (Barbrook 2006, 96), "cybertariat" (Huws 2001), or "digital labour". The prefixes "e-" and "cyber", or the modifier "digital" are used to stress one salient aspect of Internet work, which is that it depends on computers. Then one particular aspect of computers is used to refer to the world of computers in general, and by extension to the Internet: computers rely on electronics ("-e"), are a complex information system ("cyber"), based on digits ("digital"), etc. Once one of these particular aspects of computer technology has found its way into the current language as a proxy for Internet-related activity, it can be associated with a word referring to work and labour: e + freelancer = elancer, cyber + proletariat: cybertariat, digital + labour. The choice of the work-related element is of course linked with the political stance of the author. Those metonymies point to the dependence of the worker on the technology. Amazon's Mechanical Turk refers to the Turk, a chess-playing automaton that was ultimately discovered to provide a hiding place for an actual chess expert, and provides "artificial artificial intelligence". A metonymy derived from one particular aspect of work on the Internet (and thus analogous to 3.6) would be clickworker.

Most striking is the fact that no new word has emerged from the wealth of "new names" that clog the literature about the Internet to replace "to work" as a verb. This would be further

\footnotetext{
${ }^{27}$ http://www.britishsignlanguage.com/words/index.php?id=75
} 
proof that work on the Internet is definitely not virtual, since virtual is defined by the OED as "not physically existing as such but made by software to appear to do so from the point of view of the program or the user".

\section{References}

Arendt. 1998. The Human Condition. Chicago: University of Chicago Press.

Aristotle. 1957. Aristotle's Politica. Edited by William David Ross. Oxford: Clarendon Press. Available at: http://nlp.perseus.tufts.edu/hopper/

Aristotle. 2008. Davis, Henry William Carless and Benjamin Jowett. Aristotle Politics. New York: Cosimo Classics.

Armstrong, David F. and Sherman E. Wilcox. 2007. The Gestural Origin of Language: Perspectives on Deafness. Oxford: Oxford University Press.

Bacon, Francis. 1960. The New Organon and Related Writings. Edited by Fulton H. Anderson. Indianapolis and New York: Bobbs-Merrill.

Barbrook, Richard. 2006. The Class of the New. Accessed April 2, 2014. http://www.theclassofthenew.net.

Barcelona, Antonio, Réka Benczes and Francisco José Ruiz de Mendoza Ibáñez. 2011. Defining Metonymy in Cognitive Linguistics: Towards a Consensus Biew. Amsterdam: John Benjamins Publishing.

Chen, Don J.Q. and Vivien K.G. Lim. 2011. Impact of Cyberloafing on Psychological Engagement. 71st Academy of Management Meeting. San Antonio, Texas, USA, 12th-16th Aug, 2011.

Chickering, Howell D., Jr. 2006. Beowulf: A Dual-Language Edition. New York: Anchor Books.

Cleaver, Harry. 2002. Work is Still the Central Issue! New Words for New Worlds. In The Labour Debate: An Investigation into the Theory and Reality of Capitalist Work, edited by Ana Dienrstein and Michael Leary, 135-148. Hampshire: Ashgate.

Clemoes, Peter. 2006. Interactions of Thought and Language in Old English Poetry. Cambridge: Cambridge University Press.

de Oliveira e Paiva, Vera and Lúcia Menezes. 2010. A metonímia como processo fractal multimodal. Revista Veredas 14 (1): 7-19.

Dirven, René and Ralf Pörings 2003. Metaphor and Metonymy in Comparison and Contrast. Berlin: Walter de Gruyter.

Fuchs, Christian and Sebastian Sevignani. 2013. What Is Digital Labour? What Is Digital Work? What's Their Difference? And Why Do These Questions Matter For Understanding Social Media? tripleC: Communication, Capitalism \& Critique 11 (2): 237-293.

Fuchs, Christian. 2014. Theoretical Foundations of Studying Digital Labour. London: Routledge.

Gaffiot, Félix. 1934. Dictionnaire illustré Latin/Français. Paris: Hachette.

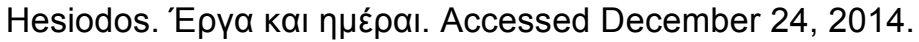
http://el.wikisource.org/wiki/\%CE\%88\%CF\%81\%CE\%B3\%CE\%B1_\%CE\%BA\%CE\%B1\%CE\%B9 \%CE\%B7\%CE\%BC\%CE\%AD\%CF\%81\%CE\%B1\%CE\%B9.

Huws, Ursula. 2001. The Making Of A Cybertariat? Virtual Work In A Real World. Socialist Register 37: 2-23.

Kley, Martin Michael. 2008. All Work and No Play? Labor, Literature and Industrial Modernity in the Weimar Left. Ph.D. Austin: The University of Texas at Austin.

Lacan, Jacques. 1957. L'instance de la lettre dans l'inconscient ou la raison depuis Freud. La Psychanalyse (3): 47-81.

Lafargue, Paul. 1883. Droit à la Paresse. Paris. Available at: http://classiques.uqac.ca/classiques/lafargue paul/droit paresse/droit paresse.html.

Langacker, Ronald Wayne. 1973. Language and its Structure: Some Fundamental Linguistic Concepts. New York: Harcourt Brace Jovanovich.

Lakoff, George and Mark L. Johnson. 1980. Metaphors We Live By. Chicago: University of Chicago.

Leroi-Gourhan, André. 1964. Le geste et la parole. Technique et langage. Paris: Albin Michel.

Liddell, Henry George and Robert Scott. 1940. A Greek-English Lexicon, Revised and Augmented Throughout by Sir Henry Stuart Jones, with the Assistance of Roderick McKenzie. Oxford: Clarendon Press. Available, with other lexicons, at the Perseus Digital Library: http://www.perseus.tufts.edu/hopper/.

Locke, John. 2000. Two Treatises of Government. In Cambridge Texts in the History of Political Thought (Series), edited by Peter Laslett. Cambridge: Cambridge University Press. 
Mackey, Albert. 1914. Encyclopedia of Freemasonry and its Kindred Sciences. New York and London: Masonic History Company.

Madan, Arthur Cornwallis. 1903. A Swahili-English Dictionary. Oxford: Clarendon Press.

Malthus, Thomas Robert. 1814. Observations on the Effects of the Corn Laws, and of a Rise or Fall in the Price of Corn on the Agriculture and General Wealth of the Country. London: J. Johnson and Co. Available at: http://www.gutenberg.org/files/4334/4334-h/4334-h.html.

Marx, Karl and Friedrich Engels. 1845/46. The German Ideology. Amherst, NY: Prometheus Books.

Marx, Karl and Friedrich Engels. 1968ff. Marx Engels Werke. Berlin: Dietz.

Marx, Karl. 1990 The Capital. Translated by Ben Fowkes. London: Penguin Classics.

Oxford English Dictionary. OED Online. December 2013. Oxford: Oxford University Press.

Pokorny, Julius. 1959. Indogermanisches etymologisches Wörterbuch. 2 vols. Bern: Francke. Available at: https://archive.org/details/indogermanisches02pokouoft.

Rey, Alain. 2012. Dire le travail: une histoire d'idées. Forum (2). http://www.revueforum.fr/2012/01/dire-le-travail-une-histoire-d\%E2\%80\%99idees/,

Ricardo, David. 1821. Principles of Political Economy. London: John Murray. Available at http://socserv.mcmaster.ca/econ/ugcm/3ll3/ricardo/Principles.pdf

Ruiz de Mendoza Ibañez, Francisco J. 2000. The Role of Mappings and Domains in Understanding Metonymy. In Metaphor and Metonymy at the Crossroads, edited by Antonio Barcelona, 109-132. Berlin/New York: Mouton de Gruyter, .

Shuōwén Jiězì. C. 100-121. http://www.shuowenjiezi.com/ gives access to the Shuōwén Jiězì (說文解字), the original etymological dictionary, and the later glosses.

Smith, Adam. 1999. The Wealth of Nations, Books I-III, edited by Andrew Skinner. London: Penguin Classics.

The Quranic Arabic Corpus. Available at: http://corpus.quran.com/.

Weber, Max. 2010. Die protestantische Ethik und der Geist des Kapitalismus, Vollständige Ausgabe. Edited by Dirk Kaesler. Munich: C.H. Beck.

Weber, Max. 2002. The Protestant Ethic and the Spirit of Capitalism and other writings, translated and edited by Peter Baer and Gordon C. Wells. Harmondsworh: Penguin.

Wilkinson, Helen. Quoted in Bar, 96.

http://www.helenwilkinson.com/ventures/founding\%20ventures.asp

\section{About the Author}

Olivier Frayssé

A graduate of École Normale Supérieure and Institut d'Études politiques de Paris, Olivier Frayssé is currently a Professor in the English Department of Paris-Sorbonne Université. His lifelong interest, whether as labour activist or researcher, has been work/labour, especially in relation with property, and the connection between work/labour, culture, and society. 